\title{
Mechanical Behaviors of Granite after Thermal Shock with Different Cooling Rates
}

\author{
Peng Xiao ${ }^{1,2}$, Jun Zheng ${ }^{1,2, *}$, Bin Dou ${ }^{1,2, *}$, Hong Tian ${ }^{1,2}\left(\mathbb{C}\right.$, Guodong Cui ${ }^{1,2}$ and Muhammad Kashif ${ }^{3}$ \\ 1 Faculty of Engineering, China University of Geosciences, Wuhan 430074, China; \\ xiaopeng805@cug.edu.cn (P.X.); htian@cug.edu.cn (H.T.); cuiguodong@cug.edu.cn (G.C.) \\ 2 National Center for International Research on Deep Earth Drilling and Resources Development, \\ Wuhan 430074, China \\ 3 Department of Earth Sciences, University of Sargodha, Sargodha 40100, Pakistan; \\ Muhammad.kashif@uos.edu.pk \\ * Correspondence: junzheng@cug.edu.cn (J.Z.); doubin@cug.edu.cn (B.D.); \\ Tel.: +86-180-7174-8712 (J.Z.); +86-189-8615-3360 (B.D.)
}

check for updates

Citation: Xiao, P.; Zheng, J.; Dou, B.; Tian, H.; Cui, G.; Kashif, M. Mechanical Behaviors of Granite after Thermal Shock with Different

Cooling Rates. Energies 2021, 14, 3721 https://doi.org/10.3390/en14133721

Academic Editor: Joel Sarout

Received: 25 May 2021

Accepted: 16 June 2021

Published: 22 June 2021

Publisher's Note: MDPI stays neutral with regard to jurisdictional claims in published maps and institutional affiliations.

Copyright: (c) 2021 by the authors. Licensee MDPI, Basel, Switzerland. This article is an open access article distributed under the terms and conditions of the Creative Commons Attribution (CC BY) license (https:// creativecommons.org/licenses/by/ $4.0 /)$.

\begin{abstract}
During the construction of nuclear waste storage facilities, deep drilling, and geothermal energy development, high-temperature rocks are inevitably subjected to thermal shock. The physical and mechanical behaviors of granite treated with different thermal shocks were analyzed by nondestructive (P-wave velocity test) and destructive tests (uniaxial compression test and Brazil splitting test). The results show that the P-wave velocity $\left(V_{P}\right)$, uniaxial compressive strength (UCS), elastic modulus $(E)$, and tensile strength $\left(s_{t}\right)$ of specimens all decrease with the treatment temperature. Compared with air cooling, water cooling causes greater damage to the mechanical properties of granite. Thermal shock induces thermal stress inside the rock due to inhomogeneous expansion of mineral particles and further causes the initiation and propagation of microcracks which alter the mechanical behaviors of granite. Rapid cooling aggravates the damage degree of specimens. The failure pattern gradually transforms from longitudinal fracture to shear failure with temperature. In addition, there is a good fitting relationship between P-wave velocity and mechanical parameters of granite after different temperature treatments, which indicates P-wave velocity can be used to evaluate rock damage and predict rock mechanical parameters. The research results can provide guidance for high-temperature rock engineering.
\end{abstract}

Keywords: high temperature; granite; cooling rates; P-wave velocity; mechanical properties; failure patterns

\section{Introduction}

The utilization of fossil energy has several worrisome environmental implications, such as the greenhouse effect and acid rain. In these circumstances, replacing gas and oil combustion with renewable energy resources can significantly reduce $\mathrm{CO}_{2}$ emissions and environmental pollution [1-3]. Therefore, clean renewable energy is the future direction of energy development and is attracting more and more attention [2,4]. Geothermal energy is a pollution-free and renewable energy source that has achieved rapid development [4-6]. Thus, many countries have focused on the exploitation of deep geothermal energy, including subsidizing deep geothermal exploitation and addressing challenges in geothermal energy production $[2,4,7]$. During deep geothermal energy exploitation, it is important to circularly pump a working fluid into an underground fracture network to realize heat extraction. Hot dry rocks (HDR) with a temperature up to $400{ }^{\circ} \mathrm{C}$ in a deep geothermal reservoir may be directly exposed to cool water and suffer great temperature gradients $[8,9]$. As a result, great temperature gradients will cause the propagation of microcracks and impact on the mechanical properties of HDR [8,9]. The effects of these changes are twofold. On the one hand, the stability of the shaft wall rock is reduced, which may lead to shaft 
wall collapse. On the other hand, the permeability of reservoir rock will increase, which is conducive to the improvement of the thermal recovery rate $[10,11]$. The effect of thermal shock on the physical and mechanical behaviors of deep rocks is also involved in other high-temperature deep rock engineering projects, such as the construction of nuclear waste storage facilities and deep hydraulic fracturing $[4,12,13]$. Geological exploration data have shown that deep crystalline rock (granite, biotite gneiss, etc.) reservoirs have sufficient geothermal energy to serve as geothermal reservoirs $[14,15]$. So, a deep understanding of the mechanical behaviors of crystalline rocks suffering drastic temperature changes is of great importance for engineering applications involving high-temperature rock mechanics $[4,16]$. It is significant to find out the change law and mechanism of mechanical properties of granite after suffering a thermal shock [4].

Past studies have shown that there is no doubt that high-temperature treatment and rapid cooling have a thermal shock on the mechanical properties of crystalline rocks. Scholars have done extensive research on the physical, mechanical, and microstructure performances of granites exposed to thermal shock $[4,5,9,10,14-24]$. Martyushev et al. confirmed that effective pressure can alter reservoir properties [25,26]. David et al. [27] found that rock microstructure has strong control of physical properties. Griffiths [28] and Fredrich [29] et al. established a link between the microstructural parameters and the mechanical behavior of rock by micromechanical models. With a thermal shock, the microstructure and the physical and mechanical properties of specimens may be changed. In general, the thermal treatment weakens the mechanical behavior and the dynamic elasticity properties of crystalline rock [30-39]. Zhao et al. [35] found that thermal shock reduces the mechanical properties of granite, especially when the temperature is over $400{ }^{\circ} \mathrm{C}$, and the mechanical behaviors of granite deteriorated sharply. A high cooling rate or high-temperature gradients means intensive thermal shock, which will make the mechanical properties of rock deteriorate more seriously. Kumari et al. [23] studied the effect mechanism of cooling rate on the physical and mechanical properties of granite and found that thermal shock will weaken the mechanical behaviors of rock, which is mainly achieved by forming microcracks in rock. Zhu et al. studied experimentally the influence of thermal shock on the physical and mechanical properties of granite and the cracking characteristics of granite under the thermal shock $[5,14,18,40,41]$. The results show that the high temperature treatment causes lots of microcracks in the specimens. The existence of microcracks increases the volume of the rock, reduces the density and $V_{P}$ of the rock, and weakens it's mechanical strength (uniaxial compressive strength, elastic modulus, etc.) [42]. Acoustic emission monitoring and ultrasonic velocity measurements can be used to study the influence of temperature on the microstructure of granite [43]. In addition, Zhu et al. [21] also explored the relationship between the P-wave velocity and the mechanical parameters of granite that underwent different thermal shocks. Shao et al. [44] investigated the fracture toughness of granite specimens after elevated temperature treatment and liquid nitrogen cooling. The scholars also considered the influence of heating/cooling rate on thermal cracking in granite, and their results confirmed that a rapid cooling rate caused more microcracks in granite [10,45-47]. However, Heap et al. confirmed that the heating/cooling rate does not alter mechanical behaviors of some rock, such as andesitic dome rock from Volcan de Colima (Mexico) [48,49]. In addition, Yang et al. [50] investigated the relationship between temperature treatment and thermal-mechanical properties by a fully coupled thermal-mechanical model.

In the above-mentioned previous studies, only some of the literature has reported the failure patterns or mechanical behaviors of granite exposed to different thermal shock. Therefore, the aim of this paper is to experimentally reveal the influence of exposure temperature $\left(25\right.$ to $600{ }^{\circ} \mathrm{C}$ ) and different cooling rates (cooling with water or air) on the mechanical behavior of granite through a uniaxial compression experiment and the Brazil splitting test. This study is expected to make a clear understanding of the mechanical behavior of high-temperature granite to provide a contribution to reservoir construction and well borehole stability during the development of geothermal energy. 


\section{Materials and Methods}

\subsection{Sample Preparation}

The granite specimens chosen in this research work were collected from Xuzhou, Jiangsu Province, China. All the specimens were cored from an identical granite block with a depth of about $200 \mathrm{~m}$ to reduce the scatter of the experimental results. Then, the specimens were processed into cylinders with $\phi 50 \mathrm{~mm} \times \mathrm{H} 100 \mathrm{~mm}$ (for Uniaxial compression test) or $\phi 50 \mathrm{~mm} \times \mathrm{H} 50 \mathrm{~mm}$ (for Brazilian split test). In order to ensure the reliability of the experimental achievement, the non-parallelism error of the two end faces and the diameter error along the height of the specimens were less than 0.05 and $0.3 \mathrm{~mm}$ respectively, and the end faces were perpendicular to the axis of the test piece with the deviation angle less than $0.25^{\circ}$, as shown in Figure 1. The main mineral compositions of the granite, which was determined by X-ray diffraction analysis, were albite $53.44 \%$, microcline $30.07 \%$, quartz $9.04 \%$, and muscovite $7.45 \%$. In order for the specimens have better uniformity and consistency which can ensure the accuracy of the experimental results, the density and $V_{P}$ of the original specimens were taken as measurements, and the abnormal rock specimens were eliminated. The average density and $V_{P}$ of the tested specimens were $2.65 \mathrm{~g} / \mathrm{cm}^{3}$ and $5365.67 \mathrm{~m} / \mathrm{s}$, respectively.

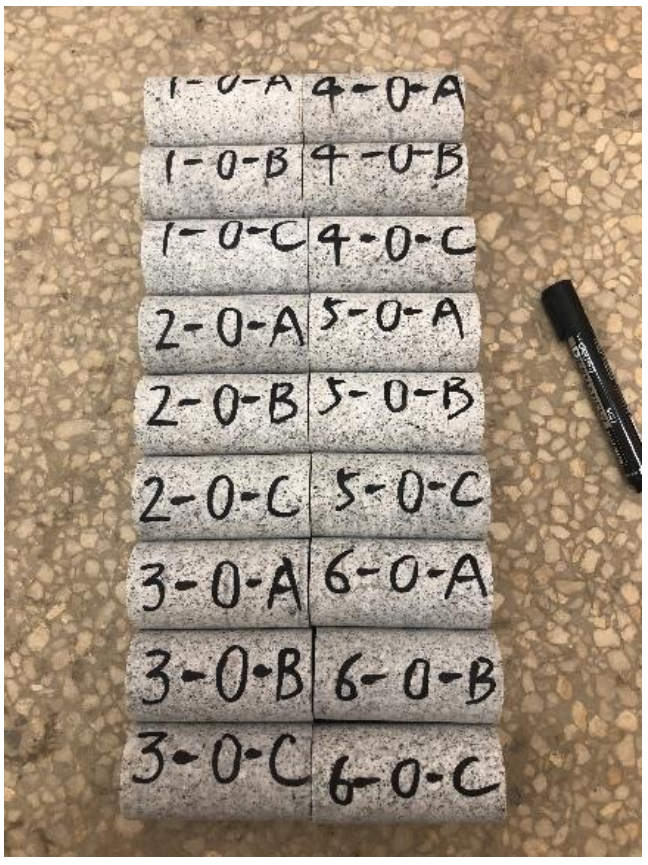

(a)

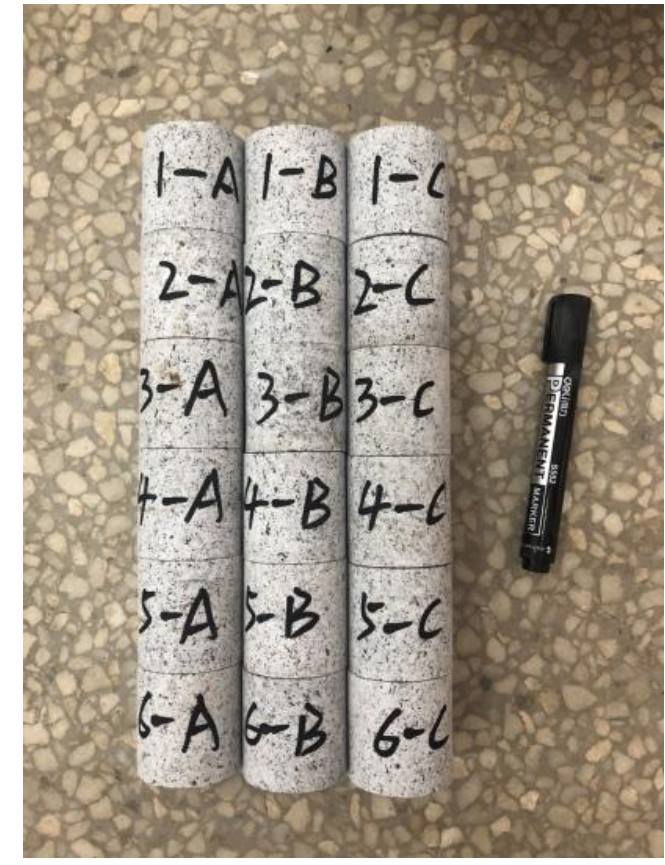

(b)

Figure 1. Granite specimens used in the test. (a) Specimens for the uniaxial compression test; (b) specimens for the Brazilian split test.

\subsection{Test Equipment}

As shown in Figure 2, the test equipment used in this study includes an SG-XL 1200 high-temperature furnace, DC-1020 constant-temperature bath, RSM-SY 5 wave velocity detector, Universal strength testing machine, and RFP-03 Brazilian split testing machine. The SG-XL 1200 high-temperature furnace applied to heat rock specimens to different target temperatures, can reach a maximum temperature of $1200{ }^{\circ} \mathrm{C}$ with a constant heating rate and maintenance of the content temperature with a temperature control accuracy of $\pm 3^{\circ} \mathrm{C}$. The DC-1020 constant temperature bath, which was used to cool the high-temperature rock specimens, maintained a constant temperature from -10 to $99^{\circ} \mathrm{C}$ with a temperature error less than $0.3 \%$. The maximum axial loading of the Universal strength testing machine was $2000 \mathrm{kN}$, and the axial loading can be performed as displacement-controlled with a 
stress resolution of $0.1 \mathrm{kN}$ or stress-controlled conditions with a displacement resolution of $0.001 \mathrm{~mm}$.

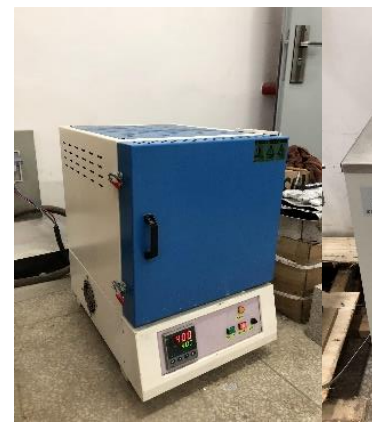

(a)

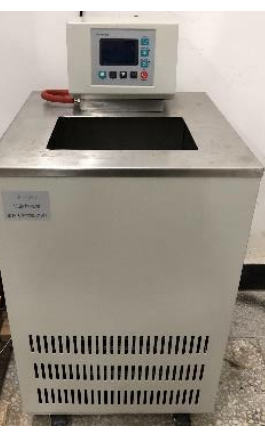

(b)

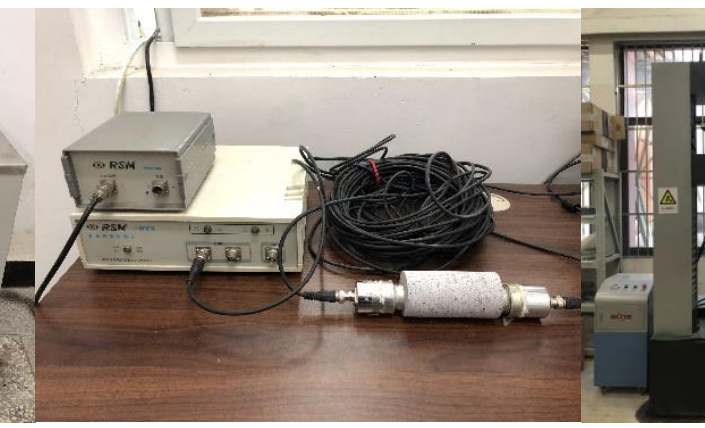

(c)

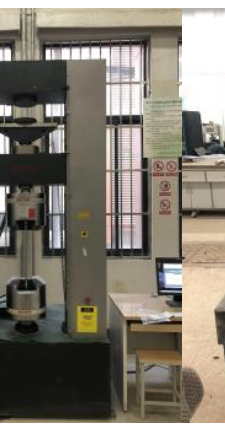

(d)

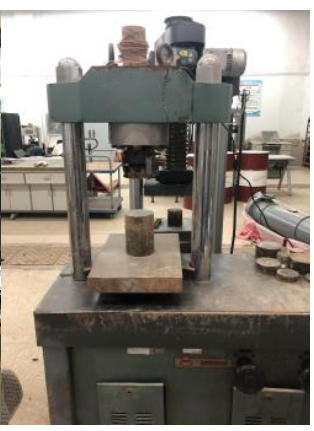

(e)

Figure 2. Test equipment used in this study. (a) SG-XL 1200 high-temperature furnace; (b) DC-1020 constant temperature bath; (c) RSM-SY5 wave velocity detector; (d) universal strength testing machine; (e) RFP-03 Brazilian split testing machine.

\subsection{Experimental Procedure}

The test flow chart is displayed in Figure 3. The treatment temperatures of specimens were $200,300,400,500$, and $600{ }^{\circ} \mathrm{C}$, respectively. According to the different aim treating temperatures, the rock specimens were put into the high-temperature furnace in batches, and the specimens were heated to each aim temperature with the heating rate of $5{ }^{\circ} \mathrm{C} / \mathrm{min}$. After realizing the target temperature, the rock specimens were maintained in the furnace at the target temperature for $2 \mathrm{~h}$ to ensure the uniform temperature distribution of the rock specimens (Figure 4). The rock specimens exposed to a high temperature were cooled with two cooling shocks. Half of the specimens were taken out from the high-temperature furnace and put into a DC-1020 constant temperature bath filled with room-temperature water to cool them to room temperature, and then put into a drying vessel, which is a closed glass container with a desiccant used to absorb water from granite samples. For the remaining specimens, they were taken out from the high-temperature furnace and directly put into the drying vessel to cool to room temperature. After the rock specimens were completely dry, the physical and mechanical tests of the rock specimens were carried out.

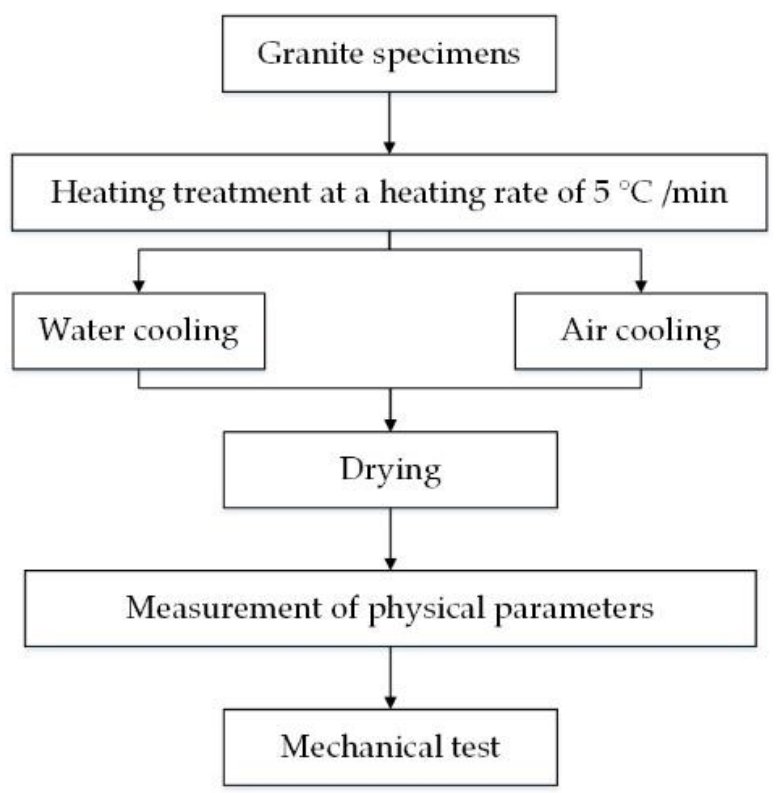

Figure 3. Experimental flow chart. 


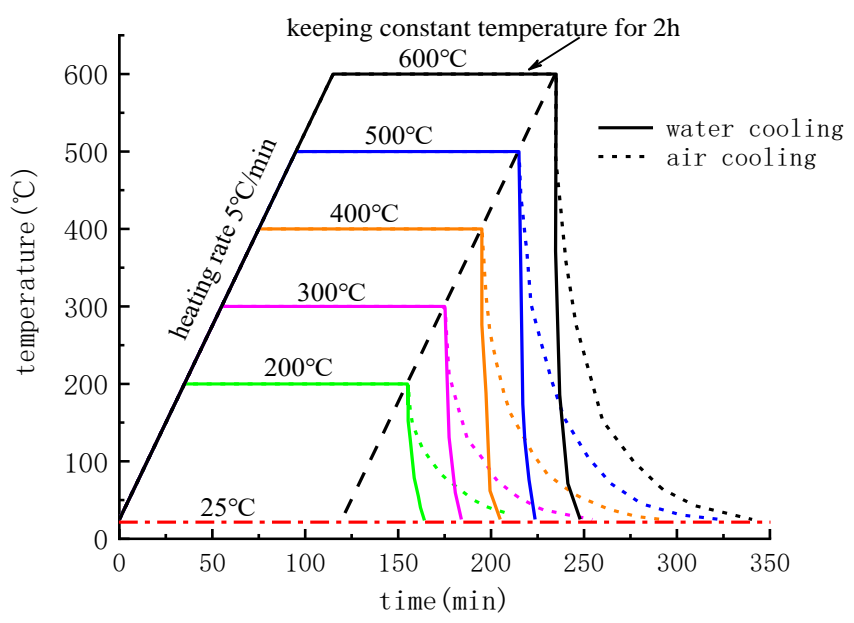

Figure 4. Testing scheme of heating and cooling processes.

For the uniaxial compression test, the treated granite specimens were put in the universal strength testing machine, and then the axial load was used at a loading rate of $0.03 \mathrm{~mm} / \mathrm{min}$ until specimens failed to determine the uniaxial compression mechanical behaviors of specimens. The stress-strain curve is automatically recorded through the universal strength testing machine during the test. For the Brazilian split test, the treated rock specimens were put into the Brazilian split testing machine, and then the radial load was applied at a loading rate of $0.5 \mathrm{kN} / \mathrm{s}$ under radial stress control until the specimens failed.

\section{Results}

\subsection{P-Wave Velocity}

The variations in $V_{P}$ of granite specimens with temperature under different cooling methods are shown in Figure 5. High-temperature treatment decreased the $V_{P}$ of rock specimens, and the decrease degree of $V_{P}$ of water-cooling rock specimens was more dramatic than that of air-cooling specimens. When the heating temperature increases from 25 to $600{ }^{\circ} \mathrm{C}$, the values of $V_{P}$ of the rock specimens cooled with water decreased by $5 \%$, $19 \%, 39 \%, 52 \%, 56 \%$, and $78 \%$, respectively, while these of air-cooling specimens decreased by $6 \%, 15 \%, 33 \%, 44 \%, 46 \%$, and $71 \%$, respectively. In different temperature ranges, the decreasing amplitude of the $\mathrm{P}$-wave velocity presents a different trend. The P-wave velocity of specimens decreased more rapidly in stage $C$ than in stages $A$ and $B$.

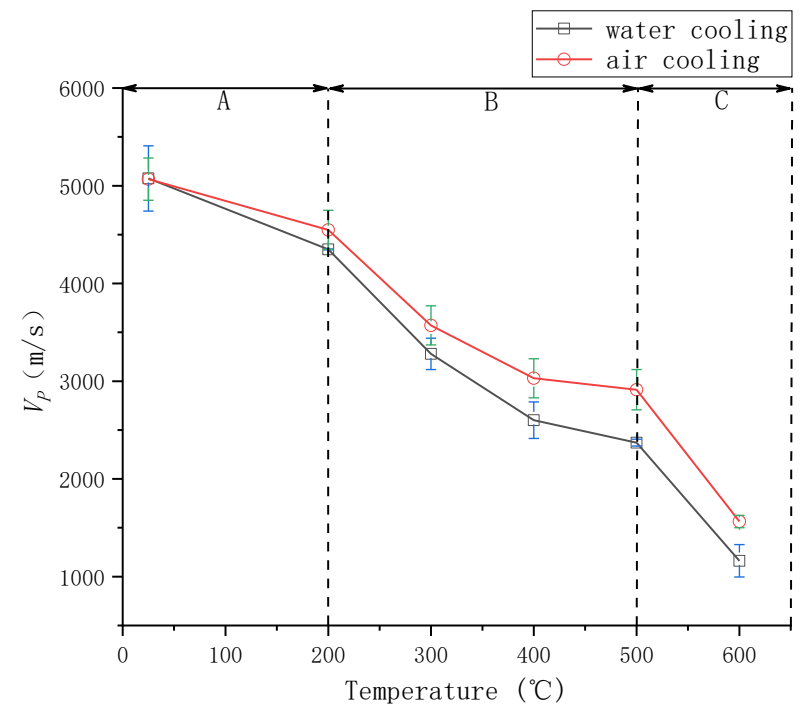

Figure 5. Variation of $V_{P}$ of rock specimens with temperature under different cooling routes. 


\subsection{Stress-Strain Relations}

The uniaxial compression stress-strain relations of specimens treated with different temperature routes are shown in Figure 6. The stress-strain relations are very similar and can be divided into four stages according to the changing characteristics: compaction, elastic deformation, yield, and failure.

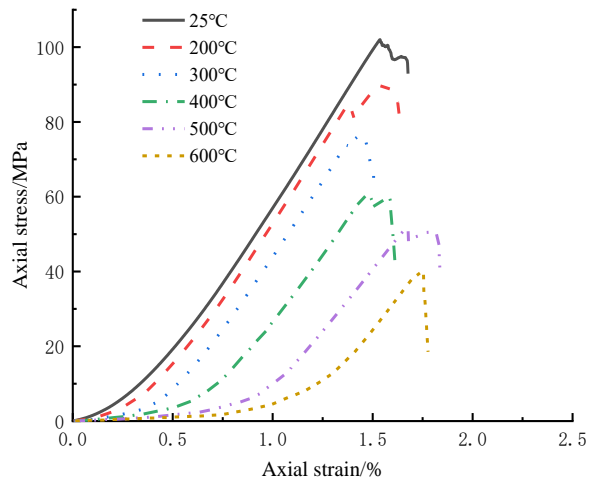

(a)

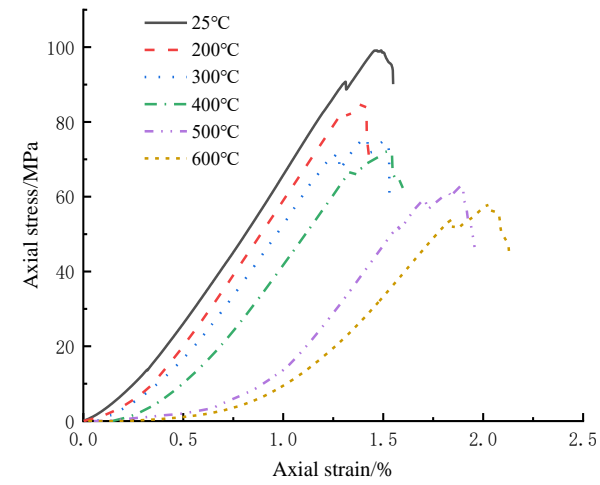

(b)

Figure 6. Stress-strain relations of rock specimens with different temperature treating routes. (a) water cooling; (b) air cooling.

As shown in Figure 6, heating temperature and cooling routes both have significant influences on the characteristics of different stages in the stress-strain curve. Under the same cooling condition, the compaction stage (the initial nonlinear part) showed a more obvious elongation tendency when the treating temperature increased from 25 to $600{ }^{\circ} \mathrm{C}$. Meanwhile, granite specimens cooled by water have a more obvious compaction stage than those cooled by air. The compaction stage reflects the closure of microcracks, and both high temperature and cooling treatment induced the generation and propagation of microcracks in the granite specimens $[30,31,51,52]$. Therefore, the variation of stressstrain curve characteristics during the compression stage indirectly indicates the quantity of augmentation of microcracks [53]. The elastic deformation stage in the stress-strain curves is close to a straight line. As can be seen from Figure 6, under the same cooling rate, the slope of the line representing the elastic deformation stage shows a downward trend with the rise in heating temperature, which indicates that the elastic modulus of the granite specimens decreases with the rise in temperature. Under the same treatment temperature, the elastic modulus of air-cooling granite specimens is higher than that of water-cooling granite specimens. The obvious yield platform stage can be observed in the rock deformation's yield stages, and the characteristics of the yield stage of granite specimens are not consistent under various experimental conditions. The peak strain of the rock specimen increases with the treatment temperature. Meanwhile, the peak strain of the water-cooling rock specimen is less than that of the air-cooling rock specimen at the same treatment temperature. The stress decreases significantly after the specimens reach the peak strength. In a word, the increase in temperature and the cooling treatment both decrease the elasticity of specimens and increase the plasticity of specimens. Cooling with water also provides the same effect, comparing to air cooling.

\subsection{Mechanics Parameters}

The UCS of granite is derived from the peak stress of the stress-strain curve. The E is defined by the tangent slope of the elastic deformation phase of the stress-strain curve from the uniaxial compression test. The splitting peak strength of granite specimens can be used to characterize the $\sigma_{t}$ of specimens, which can be obtained from the Brazilian splitting test. The experimental results are shown in Table 1. 
Table 1. Mechanical parameters of granite specimens after two different thermal shocks.

\begin{tabular}{|c|c|c|c|c|c|c|c|c|c|c|c|c|c|}
\hline \multirow{2}{*}{\multicolumn{2}{|c|}{$\begin{array}{c}\text { Cooling Route } \\
\text { Temperature } /{ }^{\circ} \mathrm{C}\end{array}$}} & \multicolumn{6}{|c|}{ Water Cooling } & \multicolumn{6}{|c|}{ Air Cooling } \\
\hline & & 25 & 200 & 300 & 400 & 500 & 600 & 25 & 200 & 300 & 400 & 500 & 600 \\
\hline \multirow{4}{*}{ UCS / MPa } & No. 1 & 94.38 & 89.93 & 71.06 & 60.72 & 47.55 & 41.20 & 102.99 & 91.37 & 73.73 & 72.26 & 69.09 & 57.02 \\
\hline & No. 2 & 102.00 & 81.30 & 76.32 & 59.44 & 51.89 & 37.33 & 102.96 & 94.50 & 82.61 & 72.09 & 61.74 & 61.71 \\
\hline & No. 3 & 95.91 & 81.02 & 71.81 & 61.98 & 56.64 & 40.34 & 99.13 & 85.11 & 76.07 & 73.17 & 62.96 & 57.80 \\
\hline & Ave. & 97.43 & 84.08 & 73.06 & 60.71 & 52.03 & 39.62 & 101.70 & 90.33 & 77.47 & 72.51 & 64.6 & 58.84 \\
\hline \multirow{4}{*}{$E / G P a$} & No. 1 & 7.99 & 7.91 & 7.38 & 6.83 & 5.99 & 5.00 & 8.09 & 7.71 & 7.84 & 7.64 & 7.27 & 5.97 \\
\hline & No. 2 & 8.09 & 7.85 & 6.92 & 6.65 & 6.16 & 5.03 & 8.25 & 8.12 & 7.85 & 7.36 & 6.85 & 6.19 \\
\hline & No. 3 & 8.01 & 7.8 & 7.15 & 6.47 & 6.27 & 5.36 & 7.96 & 8.05 & 7.5 & 7.08 & 7.36 & 6.44 \\
\hline & Ave. & 8.03 & 7.85 & 7.15 & 6.65 & 6.14 & 5.13 & 8.1 & 7.96 & 7.73 & 7.36 & 7.16 & 6.20 \\
\hline \multirow{4}{*}{$\sigma_{t} / \mathrm{MPa}$} & No. 1 & 6.16 & 5.89 & 5.15 & 4.19 & 3.08 & 1.10 & 6.14 & 6.08 & 5.89 & 4.85 & 4.02 & 1.90 \\
\hline & No. 2 & 6.18 & 5.89 & 5.09 & 4.27 & 3.09 & 1.15 & 6.14 & 6.10 & 5.87 & 4.86 & 4.02 & 1.89 \\
\hline & No. 3 & 6.14 & 5.88 & 5.18 & 4.15 & 3.08 & 1.08 & 6.11 & 6.07 & 5.93 & 4.85 & 4.00 & 1.89 \\
\hline & Ave. & 6.16 & 5.89 & 5.14 & 4.20 & 3.09 & 1.11 & 6.13 & 6.08 & 5.9 & 4.85 & 4.01 & 1.90 \\
\hline \multirow{4}{*}{$V_{P} / \mathrm{m} / \mathrm{s}$} & No. 1 & 4.69 & 4.35 & 3.45 & 2.44 & 2.38 & 1.35 & 5.27 & 4.35 & 3.77 & 3.23 & 3.14 & 1.61 \\
\hline & No. 2 & 5.27 & 4.35 & 3.26 & 2.80 & 2.40 & 1.10 & 5.09 & 4.55 & 3.57 & 3.03 & 2.74 & 1.59 \\
\hline & No. 3 & 5.26 & 4.35 & 3.13 & 2.56 & 2.33 & 1.04 & 4.84 & 4.75 & 3.37 & 2.83 & 2.86 & 1.49 \\
\hline & Ave. & 5.08 & 4.35 & 3.28 & 2.60 & 2.37 & 1.16 & 5.07 & 4.55 & 3.57 & 3.03 & 2.91 & 1.56 \\
\hline
\end{tabular}

\subsubsection{Uniaxial Compressive Strength}

The influence of different high-temperature treatments on the UCS of specimens is shown in Figure 7. As the treatment temperature increases, the UCS of specimens generally shows a nearly linear downward trend. This indicates that the mechanical behaviors of granite deteriorate significantly with the rise in temperature. When the heating temperature gradually rose from 200 to $600{ }^{\circ} \mathrm{C}$, the value of UCS of heated granite after water-cooling treatment was reduced to $88 \%, 75 \%, 60 \%, 51 \%$, and $40 \%$ of that of granite specimens without heating treatment, respectively. The value of UCS of granite specimens after air-cooling decreased to $86 \%, 77 \%, 73 \%, 64 \%$, and $58 \%$, respectively. As for the effect of the cooling route on the UCS of granite specimens, it shows a different trend before and after $300^{\circ} \mathrm{C}$. In section A of Figure 7, the cooling rate has little effect on the UCS. However, in section $\mathrm{B}$, the cooling rate had a great effect on the UCS of granite specimens, and the influence becomes more obvious with the increase in treatment temperature. Compared with air cooling, the average value of the UCS of granite specimens after water cooling from 400 to $600{ }^{\circ} \mathrm{C}$ decreased by $11.54,11.07$, and $17.46 \mathrm{MPa}$, respectively, and the reduction ranges were $15.97 \%, 17.58 \%$, and $30.20 \%$, respectively.

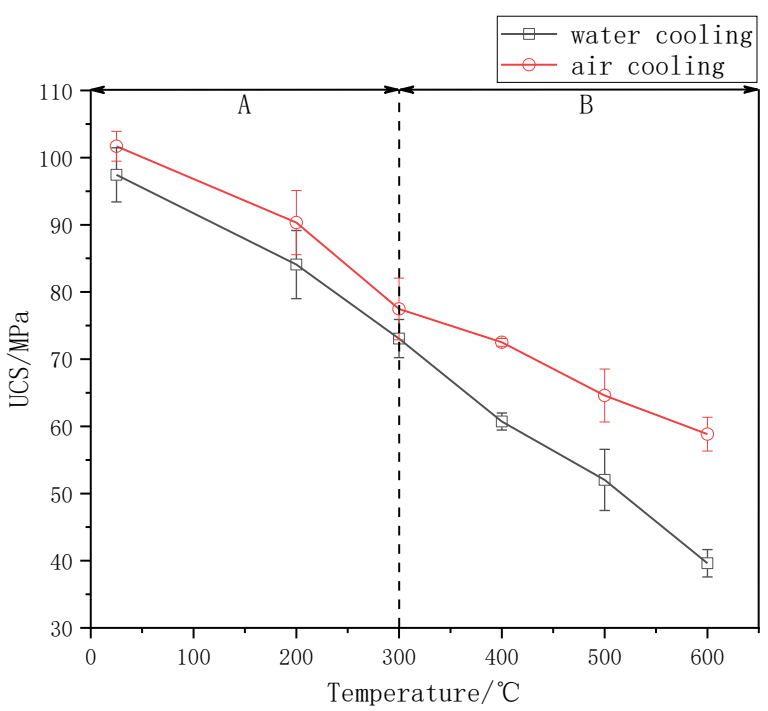

Figure 7. UCS of granite specimens treated at different temperature methods. 


\subsubsection{Elasticity Modulus}

Under the same cooling condition, the value of $E$ decreases with the increase in the treatment temperature of the granite specimen, and the decrease rate also gradually increases (Figure 8). In stage A in Figure 8, the value of $E$ of heated granite specimens after two different cooling methods changed little with temperature. However, in stages $\mathrm{B}$ and $\mathrm{C}$ in Figure 8, when the temperature rises from 200 to $600{ }^{\circ} \mathrm{C}$, the value of $E$ of water-cooling granite specimens decreases to $97.76 \%, 89.04 \%, 82.81 \%, 76.46 \%$, and $63.89 \%$ of that of original granite specimens, while the value of $E$ of air-cooling rock specimens decreases to $98.27 \%, 95.43 \%, 90.86 \%, 88.40 \%$, and $76.54 \%$, respectively. In addition, with the increase in treatment temperature, the value of $E$ of the granite specimens exposed to cooling water decreased more rapidly than that of granite exposed to air.

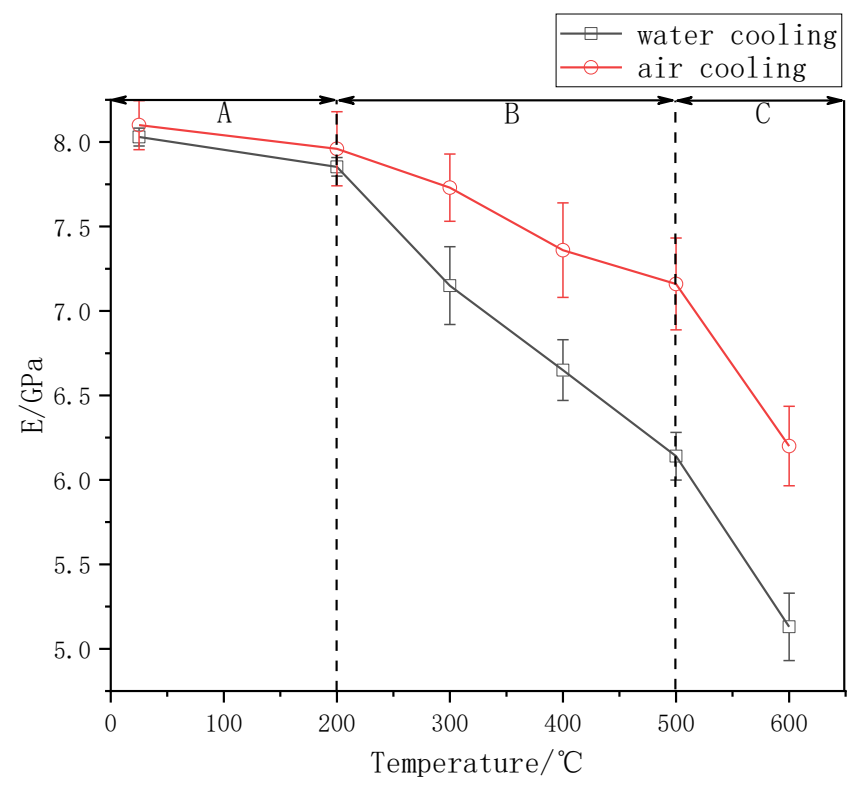

Figure 8. Relationships between temperature and elasticity modulus.

\subsubsection{Tensile Strength}

High temperature can significantly decrease the value of $\sigma_{t}$ of granite specimens with the increasing of treatment temperature. Compared to the air-cooling specimen, the $\sigma_{t}$ of the water-cooling granite specimen deteriorated more seriously (Figure 9). When the heating temperature rose from 200 to $600{ }^{\circ} \mathrm{C}$, the value of $\sigma_{t}$ of the granite specimens after air-cooling decreased by $1 \%, 4 \%, 21 \%, 35 \%$, and $70 \%$, while the granite specimens in the water-cooling group decreased by $4 \%, 16 \%, 32 \%, 50 \%$, and $82 \%$, respectively.

\subsection{Failure Patterns}

\subsubsection{Failure Patterns under Uniaxial Compression Tests}

Failure patterns of heated granite after different cooling methods under uniaxial compression tests are shown in Table 2 . The stress energy gradually accumulates in the heated granite during the loading process, and the granite specimens will suddenly break down accompanying a huge sound when it reaches a certain extent. The failure patterns of heated granite specimens are different after different temperature treatment processes. Above $300{ }^{\circ} \mathrm{C}$, the failure pattern of specimens cooled by water is mainly shear failure. However, the failure pattern of specimens cooled by air is still mixed with tension failure with the heating temperature increasing to $400{ }^{\circ} \mathrm{C}$, and the extent of the damage was lower than the water-cooling specimens. 


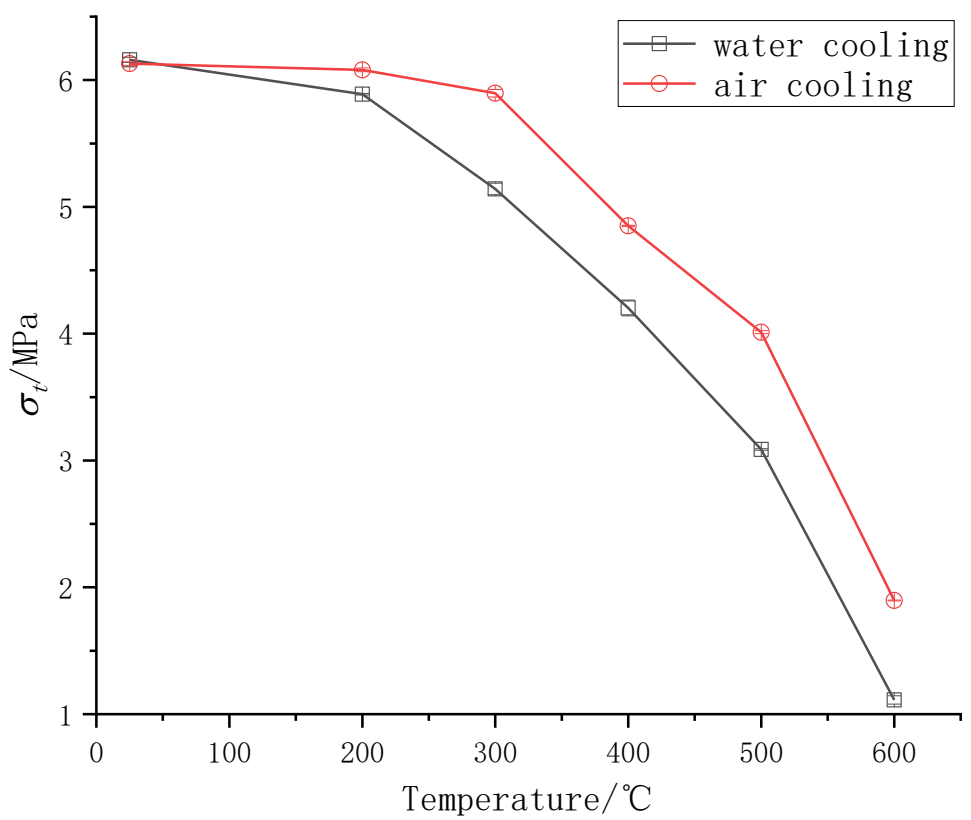

Figure 9. Relationships between temperature and tensile strength.

Table 2. Failure patterns of high-temperature granite under different cooling routes.

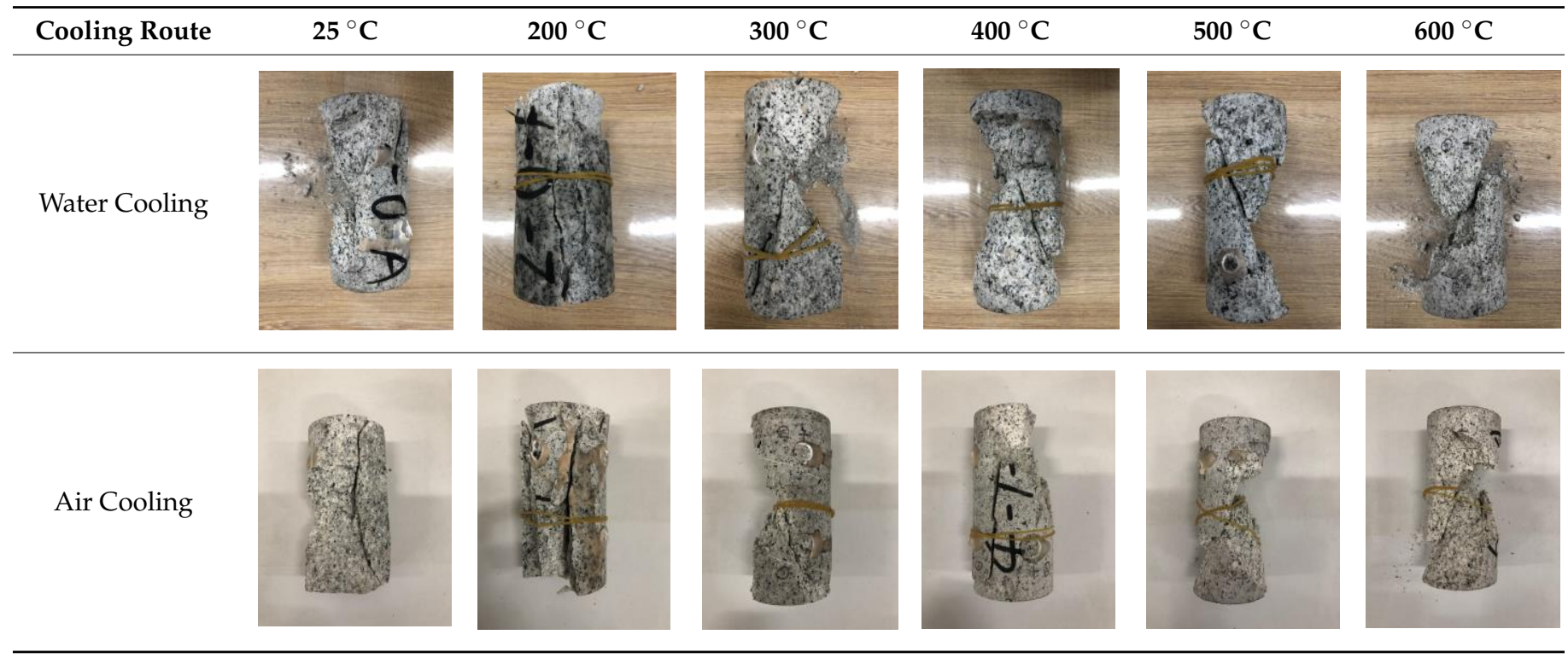

Under the same cooling condition, the failure degree of the specimens increases with treatment temperature. The volume of the block formed from the granite specimen treated by higher temperature was smaller. The cooling rates also have a significant influence on the failure pattern of heated specimens. At the same treatment temperature, the failure degree of specimens cooled by water is larger than that of the air-cooling granite specimens.

\subsubsection{Failure Patterns under Brazil Splitting Tests}

Failure patterns under Brazil splitting tests of granite specimens treated with different temperature routes are shown in Table 3. Only a radial failure path through the loading point of the specimen is generated in the Brazilian splitting tests. The granite specimens generated fragments in the Brazilian splitting tests, and the higher the temperature, the greater the amount of fragments. Meanwhile, the fracture morphology and the roughness of the failure surface of the granite specimen treated with different temperature routes 
slightly changed. Under the same cooling condition, the fracture path becomes more tortuous, and the fracture surface becomes rougher because of the increase in treating temperature, which was manifested by the larger fracture aperture. The fracture path of water-cooling rock specimens is more tortuous, and the fracture surface is coarser than that of air-cooling granite specimens. Below $400{ }^{\circ} \mathrm{C}$, the fracture path is relatively straight, and almost no fragment falls off from air-cooling granite specimens. Above $500{ }^{\circ} \mathrm{C}$, the fracture path becomes obviously twisted. However, the fracture path of water-cooling granite specimens becomes obviously twisted at $300^{\circ} \mathrm{C}$.

Table 3. Failure patterns of heated granite underwent thermal shock under Brazil splitting tests.

\begin{tabular}{|c|c|c|c|c|c|c|}
\hline Cooling Method & $25^{\circ} \mathrm{C}$ & $200{ }^{\circ} \mathrm{C}$ & $300^{\circ} \mathrm{C}$ & $400{ }^{\circ} \mathrm{C}$ & $500{ }^{\circ} \mathrm{C}$ & $600{ }^{\circ} \mathrm{C}$ \\
\hline Water Cooling & & & & & & \\
\hline
\end{tabular}

Air Cooling

\section{Discussion}

\subsection{Relationship between $V_{P}$ and Mechanical Parameters of Granite}

It is costly and time-consuming to determine the mechanical properties of rock by mechanical tests, but the non-destructive rock testing technology can solve this problem [18]. Acoustic waves would refract when they encounter cracks in the rock, which would reduce the macroscopic P-wave velocity of rocks. Therefore, the $V_{P}$ can reflect the pore structure and damage of engineering materials and is used to assess the deterioration degree of engineering materials [54]. The P-wave velocity is also used to characterize the microstructure inside the rock as a non-destructive testing method $[55,56]$. The $V_{P}$ has been employed to predict the mechanical strength to reduce the testing cost of rock mechanical properties [21].

The relationship between the $V_{P}$ of heated granite specimens after two different cooling methods are discussed in this study. Figure 10 shows the relationship between $V_{P}$ and rock mechanical parameters (UCS, $E, \sigma_{t}$ ), and a great asymptote fitting relationship between them is obtained. The relationship between mechanical parameters and $V_{P}$ is as follows:

$$
y=a-b * c^{x}
$$

where $y$ is the mechanical parameter, $x$ is $V_{P}$, and $a, b, c$ are the fitting coefficients which may depend on rock properties, such as mineral composition, joints, etc. 


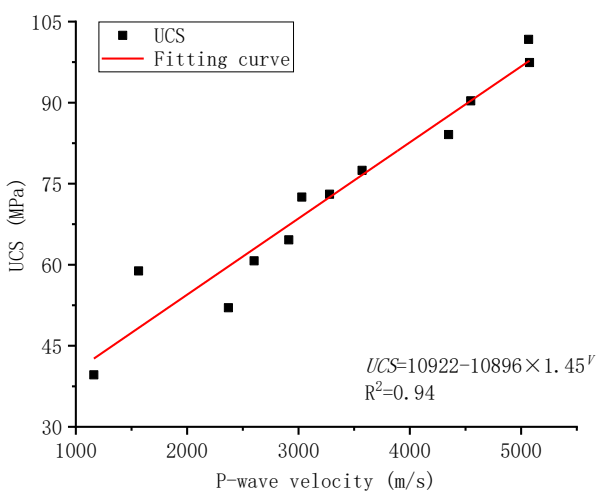

(a)

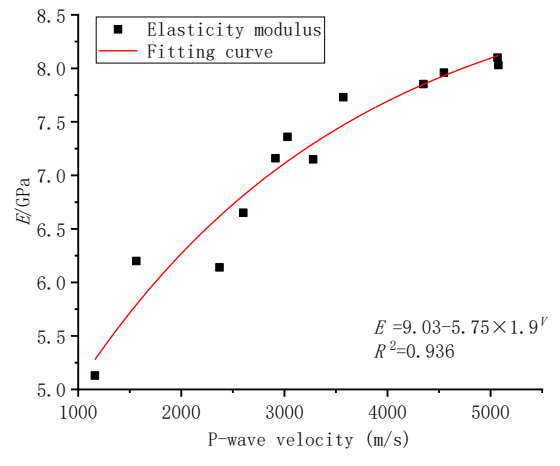

(b)

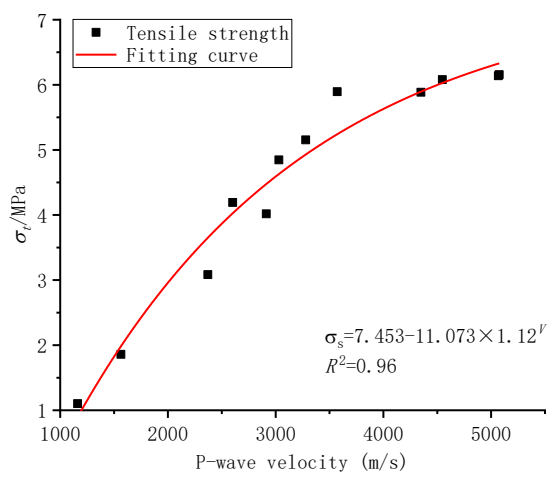

(c)

Figure 10. Relationship between $V_{P}$ and mechanical parameters. (a) Uniaxial compressive strength; (b) elasticity modulus; (c) tensile strength.

\subsection{Effect of Temperature on Physical and Mechanics Behaviors}

Thermal shock caused by heating and cooling treatment degrades the $V_{P}$ of granite specimens. In order to analyze the damage mechanism of temperature treatment on the $V_{P}$ of granite, the damage factor based on P-wave velocity was defined as follows [30]:

$$
D_{P}=1-\frac{V_{P T}}{V_{P 0}}
$$

where $D_{P}$ is the damage factor of P-wave velocity, $V_{P 0}$ represents the $V_{P}$ of the untreated specimen, and $V_{P T}$ is the $V_{P}$ of granite specimens measured at high temperatures of $T$.

The relationship between $D_{P}$ and temperature under different cooling methods is shown in Figure 11. With the increase in temperature, $D_{P}$ shows a continuous upward trend with an increasing rate, indicating that the density of microcracks constantly increases with heating temperature, and it is easier to form microcracks inside the granite specimens treated with a higher temperature. 


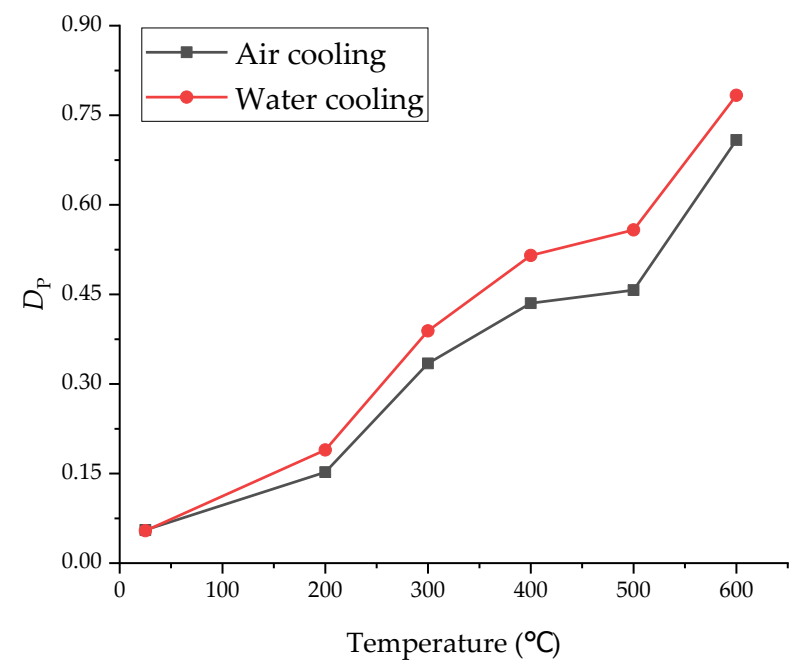

Figure 11. The relationship between $D_{P}$ and temperature under different cooling paths.

A high temperature will damage the mechanical properties of rock (Figures 7-9). In order to access the damage degree of the mechanical parameters of specimens under different thermal shock, the damage factor based on the mechanical parameters of specimens were defined as follows:

$$
\begin{gathered}
D_{U C S}=1-\frac{U C S_{T}}{U C S_{0}} \\
D_{E}=1-\frac{E_{T}}{E_{0}} \\
D_{\sigma_{t}}=1-\frac{\sigma_{s T}}{\sigma_{s 0}}
\end{gathered}
$$

where $D_{U C S}, D_{E}$, and $D \sigma_{t}$ represent the damage factor based on UCS, E, and $\sigma_{t}$, respectively. $U C S_{0}, E_{0}$, and $\sigma_{t 0}$ represent the UCS, E, and $\sigma_{t}$ of original specimens, respectively, and $U C S_{T}, E_{T}$, and $\sigma_{t T}$ are the UCS, E, and $\sigma_{t}$ of granite specimens measured at a high temperature of $T$, respectively.

With the increase in temperature, the damage degree of mechanical behaviors of specimens increases with treatment temperature (Figure 12). Meanwhile, the cooling rate also has an important influence on the thermal damage degree based on the different mechanical properties of the granite specimen. In Figure 12a, when the temperature was below $300{ }^{\circ} \mathrm{C}$, the $D_{\text {UCS }}$ of water cooling was slightly greater than that of air cooling. When the temperature was above $30{ }^{\circ} \mathrm{C}$, the $D_{\text {UCS }}$ of water cooling was larger than that of air cooling, and the difference between them gradually increased with the treatment temperature. $D_{E}$ and $D \sigma_{t}$ of water-cooling specimens were always greater than that of air-cooling granite specimens, and the difference between $D_{E}$ and $D \sigma_{t}$ with two different cooling rates increased with the increase in treatment temperature (Figure $12 b, c)$.

There are two main reasons for the damage of rock physical and mechanical parameters: (1) when the temperature of granite specimens changes dramatically, various mineral particles will expand unevenly. This inhomogeneous expansion can lead to thermal stress and further induce the generation and propagation of microcracks [34,57]. Meanwhile, the increase in treatment temperature degrades the mechanical strength of granite (Figures 7-9), and as a result, the specimens are more likely to rupture by a thermal stresscaused temperature gradient. Therefore, the increase in temperature further induces the internal microcracks in granite specimens. The presence of microfractures reduces the physical and mechanical behaviors of specimens. When the temperature is low, the thermal stress is not enough to degrade the mechanical behavior of the rock. So, when the temperature is lower than $200{ }^{\circ} \mathrm{C}$, the $D_{U C S}, D_{E}$, and $D \sigma_{t}$. of the granite are relatively small, and the influence of the cooling method on the mechanical behavior of rock is not obvious. (2) Heat 
treatment makes the composition of granite change. On the one hand, the various types of water (attached water, bound water, and constitute ion water) within the specimens evaporate at different temperature ranges $[15,16]$. On the other hand, temperature changes the mineral composition of the rocks. For example, at $573{ }^{\circ} \mathrm{C}$, quartz will undergo $\alpha / \beta$ transition $[10,45,58]$. As a result, the microcracks and micropore volume increase with temperature. Additionally, the water entering the fracture induced by thermal stress will further weaken the bonds between mineral particles, and the swelling force generated by the water boiling and vaporizing in the microcrack also provides the power for the expansion of the microcrack. Therefore, the damage degree of physical and mechanical parameters of the specimens subjected to water cooling is greater than that of air-cooling the specimens.

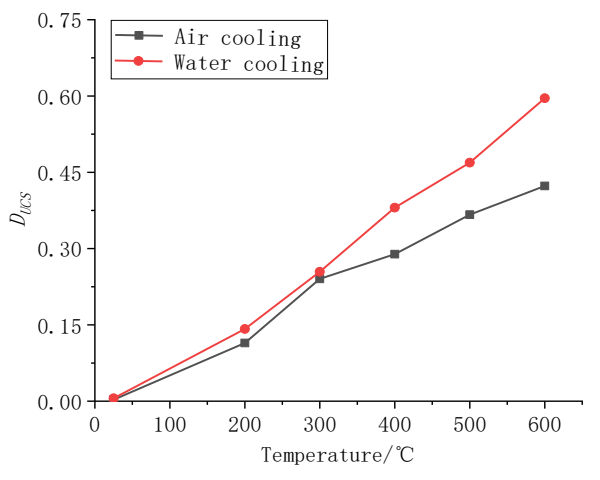

(a)

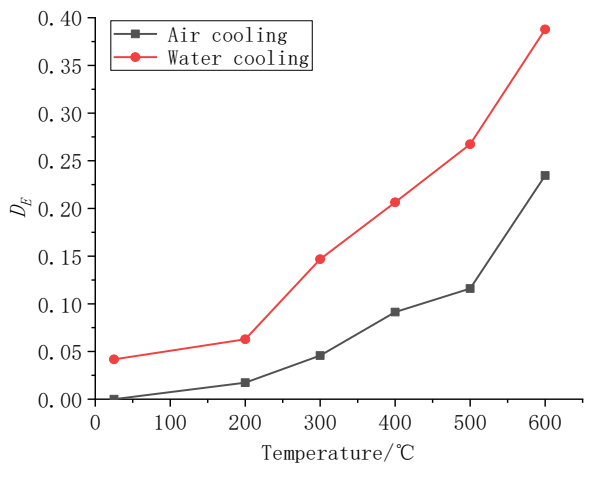

(b)

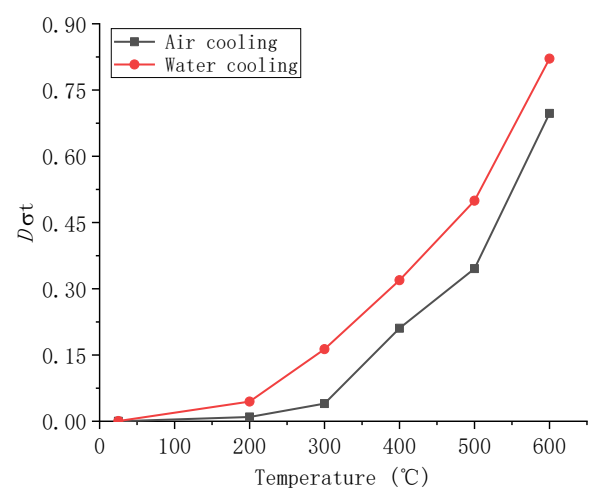

(c)

Figure 12. Relationship between temperature and thermal damage based on mechanical properties of granite. (a) $D_{U C S}$, (b) $D_{E}$, (c) $D \sigma_{t}$.

\subsection{Effect of Thermal Shock on Failure Patterns of Rocks}

The failure pattern of granite specimens treated with different temperature treatment routes changes greatly (Tables 2 and 3). The failure patterns of granite specimens conducted on uniaxial compression tests are obvious, so this part mainly discusses this. In order to quantify the failure patterns, the angle between the vertical direction of the granite specimens and the fracture surface was calculated, which is defined as the splitting angle, and the average splitting angle of rock specimens under different thermal shocks was obtained (Figure 13). It can be seen that the splitting angle gradually increases with temperature, and the rock failure pattern gradually transforms from longitudinal fracture to shear failure. This is because the number of microcracks in the rock and the degree of thermal damage increases, resulting in the decrease in the rock cohesion internal friction angle, and the continuous increase in splitting angle. 


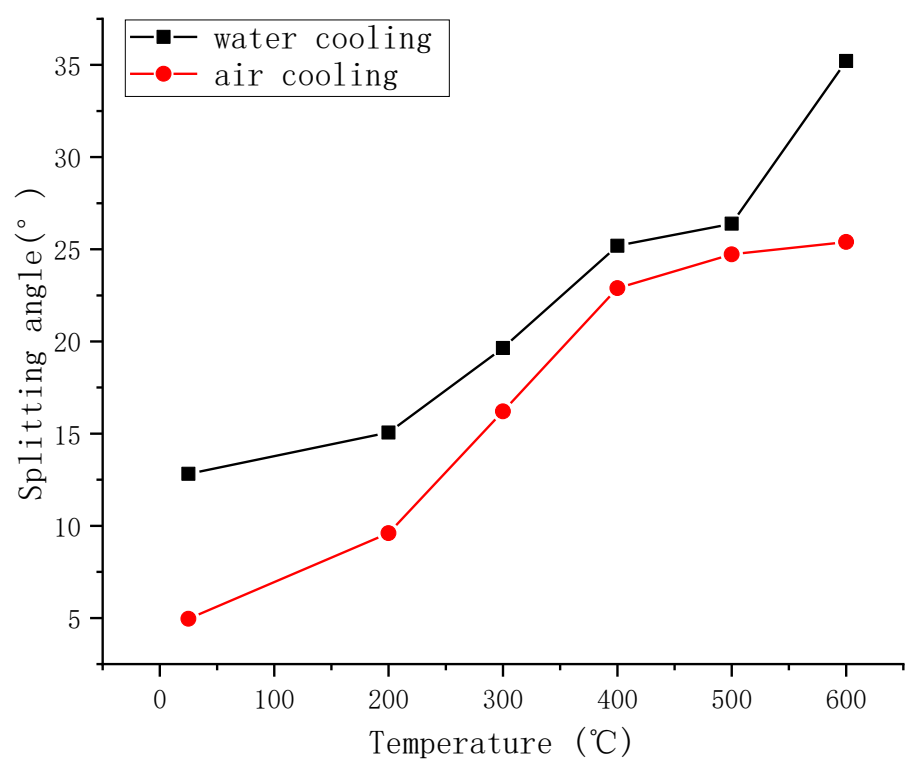

Figure 13. Relationship between rock splitting angle and temperature.

\subsection{Application of the Present Experimental Investigation}

During deep high-temperature drilling, cold drilling fluid continuously causes cooling shock to high-temperature sidewall rocks. In addition, the low temperature working fluid also continuously causes cooling shock to the high reservoir rocks during the long-term operation of the enhanced geothermal system [51]. Our studies show that cooling shock can deteriorate the mechanical behaviors of high-temperature granite. P-wave velocity, UCS, $E$, and $\sigma_{t}$ of heated granite after two cooling methods all showed a decreasing trend with temperature. Therefore, the cooling shock should be concerned in deep high-temperature rock engineering.

Our research confirms that thermal shock can generate a large number of microcracks in granite. Therefore, we can create an efficient heat recovery reservoir with lots of cracks by thermal stimulation. Meanwhile, considering that thermal shock can produce cracks in the reservoir, we can improve the permeability of the reservoir by intermittent cool working fluid injection.

Additionally, there is a good fitting relationship between P-wave velocity and rock mechanical parameters, so we can use the P-wave velocity test as a nondestructive rock testing technology to reduce cost and improve efficiency.

\section{Conclusions}

In the present article, the mechanical behaviors of granite subjected to two different thermal shocks have been studied based on mechanical experiments and an ultrasonic test technique. The main conclusions can be drawn as follows:

(1) Thermal shock has a great influence on the physical and mechanical parameters of granite. $V_{P}, U C S, E$, and $\sigma_{t}$ of heated granite after two cooling methods all show a decreasing trend with temperature. There is a great asymptote fitting between mechanical strength and the P-wave of heated granite after two cooling methods.

(2) High temperature causes uneven expansion of different minerals and further induces the development of microcracks. The degradation of physical and mechanical properties can be attributed to the generation and propagation of microcracks.

(3) Water cooling further degrades the physical and mechanical behaviors of granite, compared with air cooling. Thermal shock caused by water cooling induces more microcracks, and water permeating into granite also further causes the propagation of microcracks. 
(4) Thermal shock can change the mechanical behavior of granite specimens. The splitting angle gradually increases with treatment temperature, and the rock failure pattern gradually transforms from longitudinal fracture to shear failure. A rapid cooling rate can exaggerate the damage degree of the granite specimens.

In the future, we will further study the corresponding quantitative relationship between temperature gradient and thermal stress, which can provide a basis to predict the damage degree of rock under the action of thermal stress.

Author Contributions: P.X. conceived and designed the experiment; H.T. and J.Z. provided a guide on experiments; P.X. wrote the manuscript; B.D. and G.C. provided advice on the writing of the abstract and conclusions; B.D., H.T., J.Z., G.C. and M.K. made a significant contribution to the revision of the manuscript. All authors have read and agreed to the published version of the manuscript.

Funding: This research was funded by The National Key Research and Development Programs of China, grant number 2019YFB1504204.

Institutional Review Board Statement: Not applicable.

Informed Consent Statement: Not applicable.

Data Availability Statement: Not applicable.

Conflicts of Interest: The authors declare that they have no known competing financial interests or personal relationships that could have appeared to influence the work reported in this paper.

\section{References}

1. Majorowicz, J.; Grasby, S.E. Deep Geothermal Heating Potential for the Communities of the Western Canadian Sedimentary Basin. Energies 2021, 14, 706. [CrossRef]

2. Noorollahi, Y.; Shabbir, M.S.; Siddiqi, A.F; Ilyashenko, L.K.; Ahmadi, E. Review of two decade geothermal energy development in Iran, benefits, challenges, and future policy. Geothermics 2019, 77, 257-266. [CrossRef]

3. Mahlia, T.M.I.; Yanti, P.A.A. Cost efficiency analysis and emission reduction by implementation of energy efficiency standards for electric motors. J. Clean. Prod. 2010, 18, 365-374. [CrossRef]

4. Isaka, B.L.A.; Gamage, R.P.; Rathnaweera, T.D.; Perera, M.S.A.; Chandrasekharam, D.; Kumari, W.G.P. An Influence of ThermallyInduced Micro-Cracking under Cooling Treatments: Mechanical Characteristics of Australian Granite. Energies 2018, 11, 13386. [CrossRef]

5. Zhu, Z.; Tian, H.; Kempka, T.; Jiang, G.; Dou, B.; Mei, G. Mechanical Behaviors of Granite After Thermal Treatment Under Loading and Unloading Conditions. Nat. Resour. Res. 2021, 30, 2733-2752. [CrossRef]

6. Li, K.; Bian, H.; Liu, C.; Zhang, D.; Yang, Y. Comparison of geothermal with solar and wind power generation systems. Renew. Sust. Energy Rev. 2015, 42, 1464-1474. [CrossRef]

7. Bakhoda, H.; Almassi, M.; Moharamnejad, N.; Moghaddasi, R.; Azkia, M. Energy production trend in Iran and its effect on sustainable development. Renew. Sust. Energy Rev. 2012, 16, 1335-1339. [CrossRef]

8. Zeng, Y.; Su, Z; $\mathrm{Wu}, \mathrm{N}$. Numerical simulation of heat production potential from hot dry rock by water circulating through two horizontal wells at Desert Peak geothermal field. Energy 2013, 56, 92-107. [CrossRef]

9. Zhao, Y.; Feng, Z.; Xi, B.; Wan, Z.; Yang, D.; Liang, W. Deformation and instability failure of borehole at high temperature and high pressure in Hot Dry Rock exploitation. Renew. Energy 2015, 77, 159-165. [CrossRef]

10. Siratovich, P.A.; Villeneuve, M.C.; Cole, J.W.; Kennedy, B.M.; Begue, F. Saturated heating and quenching of three crustal rocks and implications for thermal stimulation of permeability in geothermal reservoirs. Int. J. Rock Mech. Min. Sci. 2015, 80, 265-280. [CrossRef]

11. Zhu, M.; Yu, L.; Zhang, X.; Davarpanah, A. Application of Implicit Pressure-Explicit Saturation Method to Predict Filtrated Mud Saturation Impact on the Hydrocarbon Reservoirs Formation Damage. Mathematics 2020, 8, 1057. [CrossRef]

12. Gens, A.; Guimaraes, L.D.N.; Garcia-Molina, A.; Alonso, E.E. Factors controlling rock-clay buffer interaction in a radioactive waste repository. Eng. Geol. 2002, 64, 297-308. [CrossRef]

13. Davarpanah, A.; Shirmohammadi, R.; Mirshekari, B.; Aslani, A. Analysis of hydraulic fracturing techniques: Hybrid fuzzy approaches. Arab. J. Geosci. 2019, 12, 402. [CrossRef]

14. Zhu, Z.; Tian, H.; Chen, J.; Jiang, G.; Dou, B.; Xiao, P.; Mei, G. Experimental investigation of thermal cycling effect on physical and mechanical properties of heated granite after water cooling. Bull. Eng. Geol. Environ. 2020, 79, 2457-2465. [CrossRef]

15. Fox, D.B.; Sutter, D.; Beckers, K.F.; Lukawski, M.Z.; Koch, D.L.; Anderson, B.J.; Tester, J.W. Sustainable heat farming: Modeling extraction and recovery in discretely fractured geothermal reservoirs. Geothermics 2013, 46, 42-54. [CrossRef]

16. Fairhurst, C. Nuclear waste disposal and rock mechanics: Contributions of the Underground Research Laboratory (URL), Pinawa, Manitoba, Canada. Int. J. Rock Mech. Min. Sci. 2004, 41, 1221-1227. [CrossRef] 
17. Géraud, Y.; Mazerolle, F.; Raynaud, S. Comparison between connected and overall porosity of thermally stressed granites. J. Struct. Geol. 1992, 14, 981-990. [CrossRef]

18. Zhu, Z.; Tian, H.; Mei, G.; Jiang, G.; Dou, B.; Xiao, P. Experimental investigation on mechanical behaviors of Nanan granite after thermal treatment under conventional triaxial compression. Environ. Earth Sci. 2021, 80, 46. [CrossRef]

19. Zhang, W.; Sun, Q.; Hao, S.; Geng, J.; Lv, C. Experimental study on the variation of physical and mechanical properties of rock after high temperature treatment. Appl. Therm. Eng. 2016, 98, 1297-1304. [CrossRef]

20. Vazquez, P.; Shushakova, V.; Gomez-Heras, M. Influence of mineralogy on granite decay induced by temperature increase: Experimental observations and stress simulation. Eng. Geol. 2015, 189, 58-67. [CrossRef]

21. Zhu, Z.; Ranjith, P.G.; Tian, H.; Jiang, G.; Dou, B.; Mei, G. Relationships between P-wave velocity and mechanical properties of granite after exposure to different cyclic heating and water cooling treatments. Renew. Energy 2021, 168, 375-392. [CrossRef]

22. Shen, Y.; Yuan, J.; Hou, X.; Hao, J.; Bai, Z.; Li, T. The strength changes and failure modes of high-temperature granite subjected to cooling shocks. Geomech. Geophys. Geo-Energy Geo-Resour. 2021, 7, 23. [CrossRef]

23. Kumari, W.G.P.; Ranjith, P.G.; Perera, M.S.A.; Chen, B.K.; Abdulagatov, I.M. Temperature-dependent mechanical behaviour of Australian Strathbogie granite with different cooling treatments. Eng. Geol. 2017, 229, 31-44. [CrossRef]

24. Peng, J.; Yang, S. Comparison of Mechanical Behavior and Acoustic Emission Characteristics of Three Thermally-Damaged Rocks. Energies 2018, 11, 2350. [CrossRef]

25. Martyushev, D.A.; Galkin, S.V.; Shelepov, V.V. The Influence of the Rock Stress State on Matrix and Fracture Permeability under Conditions of Various Lithofacial Zones of the Tournaisian-Fammenian Oil Fields in the Upper Kama Region. Mosc. Univ. Geol. Bull. 2019, 74, 573-581. [CrossRef]

26. Martyushev, D.A. Rock stress state influence on permeability of carbonate reservoirs. Bull. Tomsk Polytech. Univ. 2020, 8, 24-33.

27. David, C.; Menendez, B.; Darot, M. Influence of stress-induced and thermal cracking on physical properties and microstructure of La Peyratte granite. Int. J. Rock Mech. Min. Sci. 1999, 36, 433-448. [CrossRef]

28. Griffiths, L.; Heap, M.J.; Baud, P.; Schmittbuhl, J. Quantification of microcrack characteristics and implications for stiffness and strength of granite. Int. J. Rock Mech. Min. Sci. 2017, 100, 138-150. [CrossRef]

29. Fredrich, J.T.; Wong, T.F. Micromechanics of thermally induced cracking in three crustal rocks. J. Geophys. Res. Solid Earth 1986, 91, 12743-12764. [CrossRef]

30. Tang, Z.C.; Sun, M.; Peng, J. Influence of high temperature duration on physical, thermal and mechanical properties of a fine-grained marble. Appl. Therm. Eng. 2019, 156, 34-50. [CrossRef]

31. Chen, S.; Yang, C.; Wang, G. Evolution of thermal damage and permeability of Beishan granite. Appl. Therm. Eng. 2017, 110, 1533-1542. [CrossRef]

32. Khamrat, S.; Thongprapha, T.; Fuenkajorn, K. Thermal effects on shearing resistance of fractures in Tak granite. J. Struct. Geol. 2018, 111, 64-74. [CrossRef]

33. Peng, J.; Rong, G.; Cai, M.; Yao, M.; Zhou, C. Physical and mechanical behaviors of a thermal-damaged coarse marble under uniaxial compression. Eng. Geol. 2016, 200, 88-93. [CrossRef]

34. Wu, Q.; Weng, L.; Zhao, Y.; Guo, B.; Luo, T. On the tensile mechanical characteristics of fine-grained granite after heating/cooling treatments with different cooling rates. Eng. Geol. 2019, 253, 94-110. [CrossRef]

35. Zhao, F.; Shi, Z.; Sun, Q. Fracture Mechanics Behavior of Jointed Granite Exposed to High Temperatures. Rock Mech. Rock Eng. 2021, 54, 2183-2196. [CrossRef]

36. Wang, X.; Schubnel, A.; Fortin, J.; Gueguen, Y.; Ge, H. Physical properties and brittle strength of thermally cracked granite under confinement. J. Geophys. Res. Solid Earth 2013, 118, 6099-6112. [CrossRef]

37. Nasseri, M.H.B.; Schubnel, A.; Young, R.P. Coupled evolutions of fracture toughness and elastic wave velocities at high crack density in thermally treated Westerly granite. Int. J. Rock Mech. Min. Sci. 2007, 44, 601-616. [CrossRef]

38. Alm, O.; Jaktlund, L.L.; Shaoquan, K. The influence of microcrack density on the elastic and fracture mechanical-properties of stripa granite. Phys. Earth Planet. Inter. 1985, 40, 161-179. [CrossRef]

39. Zarei, V.; Mirzaasadi, M.; Davarpanah, A.; Nasiri, A.; Valizadeh, M.; Hosseini, M.J.S. Environmental Method for Synthesizing Amorphous Silica Oxide Nanoparticles from a Natural Material. Processes 2021, 9, 334. [CrossRef]

40. Zhu, Z.; Tian, H.; Mei, G.; Jiang, G.; Dou, B. Experimental investigation on physical and mechanical properties of thermal cycling granite by water cooling. Acta Geotech. 2020, 15, 1881-1893. [CrossRef]

41. Zhu, Z.; Tian, H.; Jiang, G.; Cheng, W. Effects of High Temperature on the Mechanical Properties of Chinese Marble. Rock Mech. Rock Eng. 2018, 51, 1937-1942. [CrossRef]

42. Sun, W.; Wu, S.; Xu, X. Mechanical behaviour of Lac du Bonnet granite after high-temperature treatment using bonded-particle model and moment tensor. Comput. Geotech. 2021, 135, 104132. [CrossRef]

43. Griffiths, L.; Lengline, O.; Heap, M.J.; Baud, P.; Schmittbuhl, J. Thermal Cracking in Westerly Granite Monitored Using Direct Wave Velocity, Coda Wave Interferometry, and Acoustic Emissions. J. Geophys. Res. Solid Earth 2018, 123, 2246-2261. [CrossRef]

44. Shao, Z.; Tang, X.; Wang, X. The influence of liquid nitrogen cooling on fracture toughness of granite rocks at elevated temperatures: An experimental study. Eng. Fract. Mech. 2021, 246, 107628. [CrossRef]

45. Yong, C.; Wang, C.Y. Thermally induced acoustic emission in westerly granite. Geophys. Res. Lett. 1980, 7, 1089-1092. [CrossRef]

46. Shao, S.; Wasantha, P.L.P.; Ranjith, P.G.; Chen, B.K. Effect of cooling rate on the mechanical behavior of heated Strathbogie granite with different grain sizes. Int. J. Rock Mech. Min. Sci. 2014, 70, 381-387. [CrossRef] 
47. Zhang, F.; Zhang, Y.; Yu, Y.; Hu, D.; Shao, J. Influence of cooling rate on thermal degradation of physical and mechanical properties of granite. Int. J. Rock Mech. Min. Sci. 2020, 129, 104285. [CrossRef]

48. Heap, M.J.; Coats, R.; Chen, C.; Varley, N.; Lavallee, Y.; Kendrick, J.; Xu, T.; Reuschle, T. Thermal resilience of microcracked andesitic dome rocks. J. Volcanol. Geoth. Res. 2018, 367, 20-30. [CrossRef]

49. Lu, G.; Zhou, J.; Li, Y.; Zhang, X.; Gao, W. The influence of minerals on the mechanism of microwave-induced fracturing of rocks. J. Appl. Geophys. 2020, 180, 104123. [CrossRef]

50. Yang, Z.; Yang, S.; Tian, W. Peridynamic simulation of fracture mechanical behaviour of granite specimen under real-time temperature and post-temperature treatments. Int. J. Rock Mech. Min. Sci. 2021, 138, 104573. [CrossRef]

51. Zhang, B.; Tian, H.; Dou, B.; Zheng, J.; Chen, J.; Zhu, Z.; Liu, H. Macroscopic and microscopic experimental research on granite properties after high-temperature and water-cooling cycles. Geothermics 2021, 93, 102079. [CrossRef]

52. Walsh, J.B. The effect of cracks on the compressibility of rock. J. Geophys. Res. 1965, 70, 381-389. [CrossRef]

53. David, E.C.; Brantut, N.; Schubnel, A.; Zimmerman, R.W. Sliding crack model for nonlinearity and hysteresis in the uniaxial stress-strain curve of rock. Int. J. Rock Mech. Min. Sci. 2012, 52, 9-17. [CrossRef]

54. Heap, M.J.; Lavallee, Y.; Laumann, A.; Hess, K.U.; Meredith, P.G.; Dingwell, D.B.; Huismann, S.; Weise, F. The influence of thermal-stressing (up to 1000 degrees $\mathrm{C}$ ) on the physical, mechanical, and chemical properties of siliceous-aggregate, high-strength concrete. Constr. Build. Mater. 2013, 42, 248-265. [CrossRef]

55. Jin, P.; Hu, Y.; Shao, J.; Zhao, G.; Zhu, X.; Li, C. Influence of different thermal cycling treatments on the physical, mechanical and transport properties of granite. Geothermics 2019, 78, 118-128. [CrossRef]

56. Freire-Lista, D.M.; Fort, R.; Varas-Muriel, M.J. Thermal stress-induced microcracking in building granite. Eng. Geol. 2016, 206, 83-93. [CrossRef]

57. Yang, F.; Wang, G.; Hu, D.; Liu, Y.; Zhou, H.; Tan, X. Calibrations of thermo-hydro-mechanical coupling parameters for heating and water-cooling treated granite. Renew. Energy 2021, 168, 544-558. [CrossRef]

58. Glover, P.; Baud, P.; Darot, M.; Meredith, P.G.; Boon, S.A.; Leravalec, M.; Zoussi, S.; Reuschlé, T. $\alpha / \beta$ phase transition in quartz monitored using acoustic emissions. Geophys. J. Int. 1995, 120, 775-782. [CrossRef] 